A Journal of Culture, English Language, Teaching \& Literature ISSN 1414-3320 (Print), ISSN 2502-4914 (Online)

Vol. 20 No.2; December 2020

Copyright (C) Soegijapranata Catholic University, Indonesia

Fables as Media of Environmental Education for Sentani Children in Jayapura Regency, Papua

${ }^{1}$ Wigati Yektiningtyas and ${ }^{2}$ Evalina Silalahi

${ }^{1}$ Program Studi Pendidikan Bahasa Inggris, FKIP, Universitas

Cenderawasih; Jayapura, Indonesia

${ }^{2}$ Sekolah Papua Kasih, Jayapura, Indonesia

email: 1wigati_y@yahoo.com; ${ }^{2}$ evalinsilalahi@gmail.com

Received: 17-10-2020 Accepted: 20-10-2020 Published: 30-12-2020 


\title{
Fables as Media of Environmental Education for Sentani Children in Jayapura Regency, Papua
}

\author{
${ }^{1}$ Wigati Yektiningtyas and ${ }^{2}$ Evalina Silalahi \\ 1wigati_y@yahoo.com, ²evalinsilalahi@gmail.com \\ ${ }^{1}$ Program Studi Pendidikan Bahasa Inggris, FKIP, \\ Universitas Cenderawasih; Jayapura, Indonesia \\ ${ }^{2}$ Sekolah Papua Kasih, Jayapura, Indonesia
}

\begin{abstract}
Fable is one of Sentani verbal folklore that was passed down by parents to children to teach morals. One of them is about the importance of preserving environment. Nowadays, unfortunately, fable is not frequently told anymore. Children and even most Sentani people do not recognize it. From long observation, Sentani children do not pay attention much to the nature as well. Data of fables were obtained from some informants, i.e. tribal chiefs (ondofolo, khote) and elderly people in East Sentani (Ayapo, Waena, and Asei Island) and Central Sentani (Sentani and Ifale) in 2017-2018. By adopting sociocultural approach, this paper aims to discuss about (1) the natural environment of Sentani people, (2) the use of fables in environmental education for children. This study found that (1) fable is creative and innovative materials in teaching children about environment: nature, fauna, and flora that can be done informally, nonformally, and formally, (2) children have emotional ties with the fables and want to learn more, and (3) it is an alternative way of revitalizing Sentani fables and disseminating the socio-cultural values embedded in them. This study is benefecial to motivate Sentani children to learn more about their ancestor's heritages, love their environment, and be proud of their identity.
\end{abstract}

Key words: fable, environment, Sentani folklore, revitalization

Abstrak: Fabel merupakan salah satu folklor verbal Sentani yang dahulu dituturkan secara oral dari para orang tua ke anak-anak untuk menyampaikan berbagai ajaran moral. Salah satunya adalah tentang pentingnya merawat lingkungan. Saat ini, fabel sudah jarang 
dituturkan lagi. Anak-anak bahkan sebagian orang Sentani tidak mengenalinya. Melalui pengamatan yang cukup lama, anak-anak Sentani kini tidak lagi memperhatikan lingkungan hidup mereka. Data fabel dikumpulkan dari para informan, yaitu para pemangku adat (ondofolo, khote) dan para tua-tua adat di Sentani Timur (Ayapo, Waena, dan Pulau Asei) dan Sentani Tengah (Sentani dan Ifale) pada 2017-2018. Dengan menggunakan pendekatan sosial-budaya, paper ini bertujuan untuk membahas (1) lingkungan alam masyarakat Sentani dan (2) penggunaan fabel dalam pendidikan lingkungan bagi anakanak. Studi ini menemukan bahwa (1) fabel merupakan materi yang kreatif dan inovatif untuk mengajarkan anak-anak tentang lingkungan: alam, fauna, dan flora yang dapat dilakukan secara informal, nonformal, dan formal, (2) anak-anak mempunyai hubungan emosi dengan fabel yang dipelajarinya dan ingin belajar lebih banyak fabel, (3) penggunaan fabel sebagai pengajaran merupakan cara alternatif dalam merevitalisasi dan diseminasi fabel Sentani dan nilai sosialbudaya yang terdapat di dalamnya. Studi ini bermanfaat untuk memotivasi anak-anak Sentani untuk terus mempelajari dan mencintai pusaka budaya leluhur mereka, mencintai lingkungan hidup mereka, dan bangga akan indentitas mereka.

Kata kunci: fabel, lingkungan, folklor Sentani, revitalisasi

\section{BACKGROUND}

The people of Sentani people who live on the shores of Lake Sentani, Jayapura and on some large and small islands spreading from the east to the west of this lake have a wealth of cultural heritage that is no longer recognized by most of their own people and children of Sentani, one of which is fable. Fables with legends, myths and fairy tales are a classification of folktales. Plants and animals are the main characters in the fable that can talk and behave like humans (Abrams, 2014, p. 6).

In the past, in the Sentani community, fables were passed down by parents to their children and grandparents to their grandchildren at night before going to bed and during the day as a time medium of giving advice, knowledge of taboos, customs and beliefs as well as various moral values, i.e. recommendations and prohibitions (Yektiningtyas \& Karna, 2013, p. 83). However, at this time the fable is no longer well circulated. In fact, ironically, many people, especially those who live in cities or near cities and children no longer recognize them. 
Yektiningtyas, W., \& Silalahi, E., Fables as Media of Environmental Education 237 for Sentani Children in Jayapura Regency, Papua

One of the knowledge and morals embedded in the fable is environmental education. As a traditional society, the old Sentani people were very integrated with nature so that in their daily life, they tried to maintain their existence. Two informants Ibo and Ohee on May 2018 said the old Sentani people felt they lived because of nature, and as a consequence, inversely, they respected and preserved nature. They did not cut trees carelessly, did not exploit natural products, did not spend their crops greedily, did not pollute lakes and rivers. They even maintained soil fertility.

Several Sentani fables tell the knowledge and views of the old Sentani people about the importance of conserving nature, various types of flora and fauna, as well as examples of respecting and protecting their nature. A fable entitled "Ebeu and Nangga" tells about the views of the Sentani people about the importance of preserving natural conservation. One of the characters died because he greedily finished the food. In "Black Pig and White Pig", there is a story about a family who got a miraculous blessing because they took care of the animals. "The Cassowary and her Children" and "The Sparrow and the Cassowary" (Yektiningtyas-Modouw, 2018) tell about a dense forest filled with various kinds of trees, i.e. ironwood, khukhu, mehali, soang/hoang and various kinds of sago palms, as well as various fauna, large and small, such as cenderawasih, cassowary, hawks, cuscus, crows, sparrows and yoyae birds. All of these are told to live in peace.

The four fables above provide different pictures of the nature and life of the Sentani people today. Mountains, hills and forests have become deforested due to illegal logging. Lake Sentani and rivers are full of rubbish, and rivers dry up due to illegal sand mining. As a result, floods often occur in Sentani. For example, a large flash flood occurred in March 2019 which claimed hundreds of lives and significant material losses. In addition, currently the life of fauna is not conserved. Birds of paradise, cassowaries, and other large birds cannot be or are rarely found anymore. The little birds are hunted just for fun. There are fewer fish in lakes and rivers because their habitats are full of pollution. Even children do not care about their environment, too. They destroy trees and hunt birds. This phenomenon cannot be ignored.

Based on the above background and the previous research result on "Preservation of Sentani Language using Folktales" (2018) that Sentani children like fables, this paper aims to explore Sentani's fables as media to teach the importance of environment for children, namely protecting the natural environment, fauna and flora around them in informal, nonformal, and formal education. This is in line with the ideas of Court $\&$ Rosental 
(2007, p. 409); Normawati (2016, pp. 205-206); Ernawati (2017, pp.125-126); Sukmawan \& Setyowati (2017, pp. 304-305) who claim that fables can be used to build the character of children, in this case, is the character of loving animals, plants, like cleanliness and beauty of nature.

Children are prioritized in this paper because they are the future generation of the Sentani pople who will continue their socio-cultural life. Children can learn to take care about their environment and do not make or imitate the same mistakes that have been done by previous generations. Hopefully, children can learn the importance of protecting their environment, get to know more fables as one of the cultural heritages of their ancestors, and are eager to explore more so that they will love and respect their own identity.

\section{LITERATURE REVIEW}

The word "fable" comes from the Latin "fabula" which means "little story". Abrams (2014, p. 6) says that fables are short stories that provide moral examples or principles of human behavior and actions and usually in conclusion either the narrator or one of the story characters conveys the moral message of the story. Fables are one of the oldest and most enduring forms of folk literature. A fable presents a concise fictional story, in prose or poetry, which features mythical creatures, animals, plants, inanimate objects or anthropomorphic forces of nature that are given human abilities such as verbal communication which illustrate or lead to interpretations of moral lessons.

According to Bhattacharya (2019, pp. 48-49), fable is not just a story with the character of an animal or plant but also a metamorphosis, personification or metaphor of human life. So that in the fable, animal/plant characters are "animated" so that they can speak, think, and behave like humans. The purpose of using animals or plants as characters is to avoid offensive feeling by the listeners/readers. Therefore, fables are preferred because with animal and plant figures, fables can provide social criticism and moral teachings more effectively, because listeners can get story messages without feeling offended and angry (Yektiningtyas, 2011, pp. 78-79). For example, a Sentani fable entitled "The Sparrow and the Cassowary" tells about an arrogant and cunning bird who liked to bully small birds around him. In real life, if someone is arrogant, cunning and oppresses others hears this story, $\mathrm{s} /$ he will not be offended because what is told is only an animal but in it there 
Yektiningtyas, W., \& Silalahi, E., Fables as Media of Environmental Education 239 for Sentani Children in Jayapura Regency, Papua

is a value of moral truth (Abrar, 2016, p.46; Juanda 2018, pp. 295-296). Ibo in interview on December 2018 said that through fables, the Sentani people can see their own goodness, struggle, persistence and even ignorance, pride, cunningness through animal or plant figures in the fable. Fable is a medium as a mirror for reflection: reflecting on behavior, words and even media of laughing at oneself.

One of the knowledge and morals spoken in the fable is love for the environment. As a traditional society, old Sentani people were closely integrated with nature so that in their daily lives, they really maintained their environmental existence. They did not pollute the lakes and the rivers and they did not cut trees down carelessly. If they had to cut trees for essential purposes, they would select trees that could be cut down, for example quite old trees. When making a garden, not all big trees were cut down. Interestingly, they replaced the trees that were cut down by planting new trees (Yektiningtyas-Modouw, 2011, pp.366-367; Chiparausha \& Mavhunduse, 2018, p. 709). This is related to local wisdom and knowledge of the Sentani people that large trees store water which is needed for the growth of new plants. This habit is implicitly recounted in one of Sentani's famous fables entitled "Ebi and Kandei" which tells about close friends, namely Ebi the bird (a small bird resembling a sparrow) and Kandei the fish (Glossamia beauforti) the endemic fish of Lake Sentani who paid attention much on their environment.

The closeness of the old Sentani people to nature and their desire to protect nature also occured because they felt at one with nature (YektiningtyasModouw, 2011, pp. 365-368; Finnegan, 2003, pp. 76-77) and thought that they lived because of nature. Protecting the environment is also related to the myth of the Sentani people about harmonious relationships, namely the vertical relationship between humans and gods, the horizontal relationship between humans and humans, and the harmonious circular relationship between humans and nature (Yektiningtyas-Modouw. 2011, pp. 56-58). This was also highlighted by an infomant Pepuho who said in January 2019 that the views and ways of the old Sentani people in protecting nature was proved by their healthy and prosperous life with clean water sources, thick forest, abundant fish and garden products. They were free from floods as well as landslides.

This is inversely proportional to the existence of modern Sentani society today. The lake is polluted with plastic waste and other household waste. As a result, the lake becomes shallow and dirty, the fish, especially the endemic 
Sentani fish, cannot live well and are starting to become extinct (Ohee \&Keiluhu, 2018, p. 80). The river has become dry due to illegal sand mining and the mountains are deforested due to illegal logging. The result of the modern Sentani people's indifference to their environment is the existence of floods, landslides, forest fires, very hot air and various diseases that arise, for example, diarrhea, skin diseases, asthma, etc. It is for this reason that Sentani children need to be educated about the importance of having a good natural environment and respect it (Dewi, 2017, p. 39; Lustyantie, et.al. 2019, pp. 392-393).

\section{METHOD}

\section{A. Research Type}

This reasearch is a qualitative one. This study is the development of a multi-year 2017-2018 research entitled "Preservation of Sentani Language Using Folktales" which was funded by DRPM, Ministry of Research, Technology and Higher Education of the Republic of Indonesia. Three main findings in this research are (1) Sentani folktales can be used as interesting materials to learn Sentani language, and (2) Sentani children like their ancestral folktales, especially fables. Since fable is a socio-cultural product of the Sentani people, this paper uses a socio-cultural approach, which underlines the relation of the text of the fables with context of the nature and socio-culture of the Sentani people (Laurenson and Swingwood, 1972, pp. 1115). This paper carefully examines the philosophy, tradition, and ecological knowledge of the Sentani people related to their natural environment.

\section{B. Research Subject}

The subject of the research is fables collected from informants in East Sentani (Ayapo, Waena, and Asei Island) and Central Sentani (Ifale and Sentani). From the data collected in 2017 and was enriched in 2019 there were some fables obtained as seen in the following table.

Table 1:

Table of fables data collected in East and Central Sentani

\begin{tabular}{ccl}
\hline No. & Areas & \multicolumn{1}{c}{ Fable Titles } \\
\hline \multirow{2}{*}{1} & \multirow{2}{*}{ East Sentani } & Ebi and Kandei \\
\cline { 3 - 3 } & & The Sparrow and the Cassowary \\
\hline
\end{tabular}


Yektiningtyas, W., \& Silalahi, E., Fables as Media of Environmental Education 241 for Sentani Children in Jayapura Regency, Papua

\begin{tabular}{ll}
\hline & Yokhu and Emfeu \\
2 Ebue and Nangga \\
\hline \multirow{3}{*}{ Central Sentani } & Bepaisaka and Kilipase \\
\cline { 2 - 2 } & An Arrogant Wassowary \\
\hline & Kilibahe the Kangaroo and Kilibahe the Dog \\
\cline { 2 - 2 } & The Cassowary and her Children \\
\hline
\end{tabular}

The limited number of fables collected proves that fables are not well acknowledged by most of Sentani people. On December 2018, some informants, namely Pepuho, Hendambo, Puraro said that those fables are not circulated anymore. They even suggested to have documentation of Sentani folktales so that Sentani children can read their own tales. Some parents like Felle, Nere, and Mokay are also afraid to see the fact that their children know tales like "Bawang Merah and Bawang Putih", "Legenda Danau Toba" and "Cinderella" more than their own tales.

\section{Research Procedure}

Data of fables were collected from several informants: tribal chiefs (ondofolo and khote), Sentani elders, and parents, in East Sentani (Ayapo, Waena, and Asei Island) and in Central Sentani (Ifale and Sentani) through close observation and interview. Fables were told mostly in Indonesian and some in Sentani language. They were then rewritten using children language, i.e. using simpler language that can be easily followed by the children. The so called "children fables" were written in trilingual stories: using Sentani, Indonesian, and English languages. The term of children fables also underlines the importance of having suitable topics, contents, and styles for children (Court \& Rosental, 2007, p. 408). For this paper, Indonesian version was used while other writing versions will be used for other purposes. Since the essence of the fables shown in the table is general, so for purposes of this paper, the fables were selected purposively that is telling or describing the environment and the views of the Sentani people about the environment, namely (1) "Ebi and Kandei", (2) "The Sparrow and the Cassowary", (3) "Ebeu and Nangga", (4) "Tepaisaka and Kilipase", (5) "Black Pig and White Pig", (6) "An Arrogant Cassowary", and (7) "The Cassowary and her Children". Two fables, "Ebi and Kandei", "The Sparrow and the Cassowary", were published in 2018, "Ebeu and Nangga" was published in 2021 while the rest are still in unpublished document. 
To obtain a valid and representative interpretation of fable data, Focus Group Discussions (FGD) were conducted with traditional stakeholders (ondofolo and khote), parents, representatives of parents, representatives of early childhood and elementary school teachers, representatives of Sunday School teachers, representatives of the Sekolah Adat Sentani (Sentani Customary School) as well as children's representatives in July 2019. Those fables were then tried out to teach about environment informally in some tribal chiefs' and the elders' houses in East and Central Sentani and nonformally in Sekolah Adat Sentani, Hobong (Central Sentani) and Sentani Folklore Reading Community in Waena (East Sentani). Formally, environmental teaching using fables was also done in SD YPPK Pulau Asei and PAUD Hadassah (East Sentani). Teaching-learning process was done in two months (October-November 2019). Monitoring and evaluation were done to know the children's and teachers'/parents' response. The terminology of children in this paper is those children at the age of $3-12$ years old or those who are in Early Childhood Education and Elementary Schools.

\section{FINDING AND DISCUSSION}

\section{A. Natural Environment of Sentani People}

Sentani people are blessed by God with a beautiful and fertile geographical area. They live on the shores of Lake Sentani and islands in Lake Sentani which spread across three areas, namely the East, the Central and the West Sentani areas. According to circulated myths, residents living in East Sentani (Asei Island, Ayapo Village, and Puai Village) were the first to live in the Sentani area before finally spreading to the central and western areas of Lake Sentani (Yektiningtyas-Modouw, 2011, pp. 42-45). Therefore, Sentani people recognize the term of raliwai (rali means "the east" and wai means "the west") which refers to the Sentani people who spread from the east to the west. Sentani people themselves use the term buyaka to describe their place of residence.

In Sentani language, $b u$ means "water" and yaka means "an empty place" because they live in an empty area surrounded by water (lake). This term is actually intended to distinguish Sentani people who live in the lake area from those who live on land, namely the Moi, Nimboran, and Kemtukgresi ethnic groups (Yektiningtyas-Modouw, 2011, pp. 44-45). In the past, this beautiful lake was also inhabited by various types of endemic fish, i.e. himem/temeng 
Yektiningtyas, W., \& Silalahi, E., Fables as Media of Environmental Education 243 for Sentani Children in Jayapura Regency, Papua

(Glossogobius sentaniensis), red rainbow fish/hewu (Glossolepis incicus), kandei/getegete (Glossamia beauforti), kahe (Glossamia wicmani), kanseli (Neoarius velutinus), rainbow fish/hewu (Chilatherina fasciata), snake-head cork, red cork/ kahe (Gluris margaritaceus) and sentani cork/black cork/kayou (oxyeleotris heterodon) (Ohee \& Keiluhu, 2018, pp. 82-83). This fish is the main source of food for Sentani people. In addition, in some places of the lake, there are types of lake weed where these endemic fish spawn.

Around Lake Sentani, there are sago hamlets. Various birds also live in the lake area, including cranes, kumkum, and ebi as main the character in a famous fable "Ebi and Kandei". The people of Sentani are grateful because they are surrounded by fauna, even though they are not easy to find now, for example cenderawasih, kangaroos, cassowaries, crocodiles, turtles, etc. Clean Lake Sentani water is also used as a source of clean water for the Sentani people who live on the islands.

To the north of the lake, there is the Cyclop Mountain or some call them Dobonsolo/ Hobongsolo/Robongsolo which is filled with dense forests with various types of trees. Forests also fill other Sentani lands. Several types of trees that grow in the Sentani area are ironwood trees (Intsia bijuga), soang trees (Xanthostemon sp.), matoa trees (Pometia sp.), and kombouw trees (Ficus variagata) which have almost disappeared due to human ignorance in managing nature. Several rivers also flow in Sentani, namely the Koyabu River, the Hubai River, the Makaole River, the Kleblouw River, the Taban River, the Klandili River and the Abeale River. Besides producing fish, these rivers are also a source of clean water for the community. In addition, in these rivers there are various stones that are used by the community to make axes, both axes for cutting trees and special axes that are used as a dowry (roboni) (Yektiningtyas-Modouw, 2011, pp. 8-9) The natural beauty of Sentani, fauna, and flora become the characters and setting of the fables, which unfortunately some of them have become extinct.

\section{B. The Use of Sentani Fables in Environmental Education for Children}

Through the selected fables, namely "Ebi and Kandei", "The Sparrow and the Cassowary", "Tepaisaka and Kilipase", "Black Pig and White Pig", "An Arrogant Cassowary", "Ebeu and Nangga", and "The Cassowary and her Children", this paper discusses the views and ways of the old Sentani people in preserving their environment, which are presented in some of the fables mentioned above, both explicitly and implicitly. The discussion focused on (1) 
the natural environment: water, land, mountains and forests, (2) fauna, and (3) flora.

For the old Sentani people, water, land, mountains and forests were very important to them because they felt they were part of nature; they depend on nature and inversely they have to take good care of it (Finnegan, 2003, p.76; Ahi, et.al., 2014, p.2; Chiparausha \& Mavhunduse, 2018, p. 709). Some informants, namely Ibo, Pepuho, and Monim on November 2018 also underlined that mistakes in managing land, water, forests and mountains will result in reduced yields of fish and gardens or crop failure, floods, forest fires, landslides, and even illness. The old Sentani people's attention to the environment and their local wisdom in caring for nature is shared by them through their fables to their children and grandchildren so that they also have an awareness of the importance of a good environment. For example, a fable entitled "Ebi and Kandei" which tells about close friends, namely Ebi (a bird) and Kandei (a fish) who planned to make a garden. In the story, the two friends are told going along the edge of the lake, from one island to another in search of the right land for gardening.

Arriving at their intended place, the two of them immediately got off and looked at the place there. After that, Kandei asked Ebi, "What do you think? Let us do gardening in this place". They saw that the vegetation there was very fertile because the land was covered with topsoil carried by the river. (Yektiningtyas, 2018, p. 10)

From the above story, it can be seen the local wisdom of the Sentani people in gardening. They chose fertile land that helped them in producing good crops in the future. The fertile land was not only God's grace since Sentani people lived near water sources and dense forests, but also because the people were wise in managing the land. Pepuho, an informant in 2017 said that in order not to become barren, the Sentani people did not burn land to open gardens. They always cut trees down and uprooted the weeds. They kept moving from one place to another place to make new gardens and let the old places fertile again.

In "Ebeu and Nangga", "Tepaisaka and Kilipase", as well as "Ebi and Kandei", the characters in these fables are told rowing through Lake Sentani which was clear, clean, and filled with various types of fish. On their way, they did not pollute the lake by throwing trash. In our interview, Ibo, Ohee, and Monim on December 2017 also said that clean lake or river in the old Sentani 
Yektiningtyas, W., \& Silalahi, E., Fables as Media of Environmental Education 245 for Sentani Children in Jayapura Regency, Papua

community did not come automatically. They maintained it by not littering. They even managed the water purposes such as for drinking/cooking, washing and bathing that were strictly obeyed. Those who still believed in "god of water" trusted that if the lake became dirty, god would be angry and would not send them fish anymore (Yektiningtyas-Modouw, 2011, pp. 56-57).

Fauna is also described in Sentani's fable, both explicitly and implicitly. In "The Sparrow and the Cassowary", "Ebi and Kandei", "Ebeu and Nangga", "Black Pig and White Pig", "Tepaisaka and Kilipase" and "An Arrogant Cassowary", various animal figures are told which unfortunately are rarely seen in Sentani now. For example, cassowaries, cuscuses, ebeu (turtles), and kangaroos cannot be easily found in Sentani. In "Tepaisaka and Kilipase" which tells about the feud between a dog and a kangaroo show us different phenomena as follows.

The dancers' whole bodies were decorated with various bird feathers, such as cenderawasih, mambruk, cockatoo, kumkum and flowers and various kinds of leaves. Kilipase himself put a bird of paradise as a decoration on his head and brought a holoboi ${ }^{1}$ (Yektiningtyas \&Gultom, 2018, p. 205)

Through the pieces of the story above, it can be seen some fauna which are no longer easily found, for example, such as cenderawasih, mambruk, cockatoos, and kumkum birds. Likewise, in "Ebi and Kandei", it was told some fauna like crocodiles (kayikulung), birds of yese, ayebalo, and olaiwa which are rarely seen today. In "An Arrogant Cassowary" it is described an arrogant cassowary who lived in a beautiful forest filled with various animals which are now becoming rare.

In ancient times, in the forest, there were some animals that lived peacefully, namely the eagle, the wafur and the cuscus. One day there was a group of butterflies singing and sucking honey. Unexpectedly, the cassowary came and got angry. The cassowary regarded that the flowers belonged to him. (Yektiningtyas \&Gultom, 2018, p. 198)

The kandei fish (Glossamia beauforti) as the main character of "Ebi and Kandei" is hard to find and even if it does exist, the price is already very expensive. Ramses-Ohee, a 90 year-old Waena ondofolo, on July 2018 explained

\footnotetext{
${ }^{1}$ Holoboi is a string bag from Sentani.
} 
that when he was a child, he used to see a variety of fauna identified and mentioned in the above fables: cenderawasih, cassowary, kangaroo, crocodile, turtle, eagles, mambruk, cockatoo, kumkum, kandei fish, etc. According to him, at that time the fauna were easily found because their habitat, both lakes and forests, were very supportive: clean lakes and dense forests. In addition, the community did not hunt these animals for fun. The local wisdom of the Sentani people, which teaches the causal balance between humans and nature, was properly maintained. People were aware that if nature was damaged or even extinct, they would experience famine, disease, and even death (Yektiningtyas-Modouw, 2011, p. 366; Ahi, et.al., 2014, p.3; Chiparausha \& Mavhunduse, 2018, p. 709).

Besides telling about water, land, mountains, forests, and fauna, fables also tell about various kinds of flora around the Sentani people. "The Cassoway and her Children" tells about a cassowary and her children who lived in a dense forest that produced many kinds of fruits which became their food. They could also play among the trees. "An Arrogant Cassowary" and "The Sparrow and the Cassowary" also tell about a dense forest full of trees as their habitat (Normawati, 2016, p. 202). In some of these fables, there is no explanation about the types of trees usually found in Sentani forests, for example in the Kampwolker forest and in Mount Cyclop, but according to Ibo on July 2018, the forests in Sentani used to be overgrown with special trees like ironwood (Intsia bijuga), soang/hoang tree (Xanthostemon sp.), matoa tree (Pometia sp.), and kombouw tree (Ficus variagata). The soang or hoang tree, according to Ohee on July 2018, is a special tree because the wood can last hundreds of years. This can be proven by the poles of the stilt houses on Asei Island that are still firmly standing even though the house was built hundreds of years ago. It is said that the longer the wood is in the water, the stronger it will be. In fact, according to them, previously this soang wood was used as a dowry (robhoni) because of its quality. Meanwhile, in the past, khombou bark (ficus variagata) was used as clothing for the Sentani people and is now used as a canvas for bark painting (malo) produced by the people of Asei Island and it is the only painting in Papua. In addition, through "The Cassowary and her Children" it is told about a cassowary and he children took a walk in the sago forest. Although it is not explicitly stated in the story, Sentani people know some types of sago (Metroxylon sp.), which in Sentani society are known as fi, among them are yeba, follo, ninggi, bane, isa, mano, yameha, otekulu, and para (Yektiningtyas -Modouw, 2011, p. 189). The lake weed as mentioned in "Ebi and Kandei", "Ebeu and Nangga", "Tepaisaka and Kilipase" is in fact divided into at least four types, namely neli, fakhou, hului, and fewake (Yektiningtyas - 
Yektiningtyas, W., \& Silalahi, E., Fables as Media of Environmental Education 247 for Sentani Children in Jayapura Regency, Papua

Modouw, 2011, pp. 188-189). Just like the fauna discussed above, these types of flora are no longer easy to find. The trees have been logged illegally with no replanting. Sago forest has been sold and turned into offices, shops and housings. A dirty lake killed the lake weed and affects the fish's life because the fish spawn among the lake weeds. The result of this damage is floods, reduced food and very hot temperatures, which all lead to the emergence of various diseases.

Ibo and Ohee in on January 2018 underlined the old beliefs and local wisdom of the Sentani people about flora. Their belief in a "god of tree" who lived in large trees made the old Sentani people not greedy in utilizing trees, even for the needs of making houses, boats, and food. They planted new trees to replace trees that were felled down. They maintained a balance between the availability of flora for a certain time and the needs of their life for food.

\section{Reflection on the Importance of Environmental Learning}

Observing several fables that tell about the environment of the Sentani people, the views and ways of old Sentani people in preserving their living environment and the phenomena of natural damage, namely water, land, forests, mountains, fauna and flora, this paper underlines the importance of social awareness in the form of the revitalization of fables, which is to revive the fables by actively retelling the children, informally at home, nonformally in learning communities and Sekolah Adat Sentani, as well as formally at school through integrated curriculum.

Children are considered as an important generation to pay special attention to because they will continue the lives of the Sentani generation in the future. The existence of Sentani people in the future depends on children who love, take care of nature and are proud of their identity. Gusal (2015, pp. 3-4), Silalahi (2015, pp. 35-40), Ernawati (2017, pp. 125-126), and Juanda (2018, p. 298) in line with this paper also highlight the important benefits of fables in building children's character and as a medium for education for the soft skills of life.

These days there is a shift in the Sentani family traditions. If in the past, grandparents and parents often told their children and grandchildren fables, where now children prefer to watch TV. Ideally, as the first and foremost informal educational institution, families have big roles in giving examples of good attitude and teaching their children about environmental education before sending them to Sunday School or formal school teachers (Abu-Ravia \& Yaari, 2012, pp. 170-171; Yektiningtyas and Morin, 2020, p. 124). By 
providing them with enough good knowledge and parental examples, children will not be easily distracted by bad habits that occur in today's society, for example various non-educational games, smoking, inhaling aica aibon glue, and other crimes. A child observer, Mebri-Noya on January 2018 said that many children today are affected by this bad activity. It is hoped that by reviving the habit of storytelling from parents to their children it will avoid them from this bad influence and make them to feel happier at home. Some parents in the discussion on January 2019 assumed that the fable used to teach about the natural beauty of Sentani and the view of the community on the importance of a clean and healthy living environment will train children to care about the cleanliness of their rooms, houses and their home environment.

In addition to building good emotional relationships between parents and children, according to Vigotsky (Fani \& Ghaemi, 2011, p. 1550) storytelling also provides scaffolding to children in forming good character and personality and basic knowledge of the natural and socio-cultural environment. Sekolah Adat Sentani and learning communities in Sentani are expected to take part in storytelling and teach about the importance of preserving their environment. Thus, they can provide reinforcement about the knowledge that parents have previously conveyed at home (Yektiningtyas and Morin, 2020, p. 125).

Empirically, the authors have also done storytelling activities like this in Sekolah Adat Sentani (Sentani Customary School) in Hobong, Central Sentani, and Sentani Folklore Reading Community in Waena (East Sentani) which has received positive responses from the children and parents. They were passionate about hearing the stories and trying to connect them with the nature, fauna, and flora in their environment that they have seen and lived in. They even said that they wanted to listen to more fables and asked the parents/grandparents to tell them, This is highlighted by Monim, the principal of Hobong Customary School in 2018. This phenomenon is called as "emotional ties" by Lazar (2002, p.19) which is one of the effectiveness of using fables as learning sources.

Formally, because fables contain satire, advice, or moral values, fables are an effective way of advising people and those who are being advised do not feel that they are being lectured. Therefore, fables are also effective media to be used in formal education in Early Childhood Education and Elementary Schools in integrated language learning, social studies and science (Brumfit, 1987, pp. 22-24; Lazar, 2002, pp. 15-19; Ernawati, 2017, pp. 125-126; Juanda, 
Yektiningtyas, W., \& Silalahi, E., Fables as Media of Environmental Education 249 for Sentani Children in Jayapura Regency, Papua

2018, p. 298). This is also related to the spirit of the 2013 Curriculum (Kemendikbud, 2016) which provides oppotunities as much as possible for teachers to explore natural and socio-cultural learning contexts at school.

There is a mistaken opinion in society that the curriculum (content) shapes the context (natural environment and socio-culture). The truth is that "content is shaped by context" (Modouw, 2021, pp. 33-34; Laurenso \& Swingwood, 1972, pp. 11-15). Thus, the richness of the curriculum depends on the ability, willingness, and readiness of teachers to explore the environment and use it in learning activities. This is in line with Swingwood's idea about the importance of infusing socio-cultural context in teachinglearning process.

In connection with the Sentani fable, fables can be used as innovative and creative materials for students to learn the importance of the environment. In addition, similar to Lazar's idea (2002, p.19) on the close relation between the learner and literary work, fables as part of the cultural heritage of the Sentani people will make students have an emotional connection with what they learn so that learning becomes more enjoyable (Yektiningtyas and Modouw, 2017, pp. 44; Juanda, 2018, p. 297).

There are certain advantages that students get when they study material that has a connection with local nature and culture. They understand quickly the learning materials given, have more emotional attachment, and the classes atmosphere are interesting and challenging (Lazar, 2002, pp. 15-19; Yektiningtyas \& Modouw, 2017, pp. 43-44). It is easier for them to describe some names of fish, birds, and trees. In addition, they are also enriched in terms of knowledge of the Sentani fables and the moral values, culture and local wisdom embedded in them. It is like the saying "once rowed two three islands exceeded". Culture and education cannot be separated.

By introducing fables to children at home, learning centers/community agents, and schools, it is hoped that children can learn the wisdom of old Sentani people in managing nature. In addition, fables can provide knowledge about fauna that have been extinct or nearly extinct. Sentani endemic fish that are starting to become extinct because people do not keep the lake clean can be reintroduced.

According to Ohee \& Keiluhu (2018, pp. 82-83), the extinction of these endemic Sentani fish, one of which is the kandei fish (Glossamia beauforti), also as one of the characters in "Ebi and Kandei", is the result of the failure of the Sentani people in maintaining the cleanliness of the lake. The lake 
pollution causes various lake weed as a place for fish laying eggs also dead. Besides, the introduction of fish from outside of Lake Sentani also threatens the life of endemic fish, some of which are betik (Ababas testudineus), tambakan (Helostoma temmincki), Sepat siam (Trichopodus pectoralis), toraja cork (Channa striata), read louhan (Amphilopus iabiatus), black louhan (A. citrinellus), mujair (Oreochromis mossambicus), nila (Oreochromis nilotica), mata merah (Systomus rubripinnis), nilem (Osteochillus vittatus). Through fables, children can also be introduced to fauna that have never been found in their life, but mentioned in the fables, such as cenderawasih, kangaroos, cuscus, cassowary, mambruk, kumkum, turtles, eagles, cockatoos, etc.

From the trials in some tribal chiefs' homes in October-November 2019, it was found that children loved listening to fables and there were some significant changes of children habbits in maintaining their environment: they liked cleaning their room, house, and yard. They did not throw garbages to the the lake and rivers. Some parents said that the children did not destroy trees and hunted small birds anymore. Teachers and parents in Sekolah Adat Sentani, Folklore Reading Community, PAUD Hadassah, and SD YPPK Pulau Asei said that children could enthusiastically explain species of flora as well as fauna in Sentani and decided to preserve them. They can also recognize trees that rarely grow in Sentani forest due to the illegal logging, for example ironwood trees, soang trees and khombouw trees and various types of sago. In addition, environmental education through the use of fables provides awareness for children not to repeat or imitate the lifestyle of the modern Sentani people, for example polluting the lake and the rivers, defoliating forests and mountains which results in the reduction or extinction of several types of fauna and flora. Interestingly, children understand that various natural disasters such as floods, landslides and forest fires and various diseases threaten people's lives when nature is damaged. Parents also said that their children prefer reading story books and listening to folktales telling to watching TV or playing games on the mobile phone. Puraro, a parent on November 2019 also underlined that children need to be taught from an early age to keep their room, yard, school and environment clean by not littering, not hunting birds with slingshots and destroying vegetation. Sandra-Monim, one of the parents also witnessed that she and some parents were challenged by the initiative of using fables in teaching environment in Sentani. She was aware that she was too busy that she ignored their children and her own cultural heritage. She decided to relearn and tell it to her children. 
Yektiningtyas, W., \& Silalahi, E., Fables as Media of Environmental Education 251 for Sentani Children in Jayapura Regency, Papua

\section{CONCLUSION}

As part of the cultural heritages of Sentani, fables are literary works that are rich in knowledge, socio-cultural values, and moral-spiritual teachings. One of the knowledge, philosophical values, and moral teachings contained in the fable is the importance of the environment. Sentani's beautiful and wellordered nature, the richness of fauna and flora with various views of the old Sentani people about its existence and how to protect it are told in the fables. When nature is damaged, most of Sentani's endemic fauna and flora become extinct due to human negligence and ignorance. Education is needed through the revitalization of the fable by retelling it to children as the relay generation of the Sentani people who will determine the future and existence of the Sentani people.

The delivery of fables can be started at home as the first and foremost educational institution, which is then supported by the community through fables telling in community agents or customary schools which are also responsible for the existence of the Sentani's cultural heritage. These two activities can be formally strengthened in schools so the schools can build the content of the curriculum obtained from the natural and local cultural context of the Sentani people. By using fable as an environmental education material, it is hoped that children will gain knowledge about the importance of environmental conservation. Fables as one of the cultural heritages of Sentani can be recognized by children as their heirs. In summary, this paper concludes a number of things, namely (1) the fable is an alternative and innovative material in delivering environmental education: nature, fauna and flora 2) children have emotional ties with the fables and want to learn more, (3) the inclusion of fables in environmental education is also a revitalization of Sentani fables and the dissemination of socio-cultural values embedded.

The attention of the local government of Jayapura Regency via the Department of Education and Culture is expected to support by providing various research facilities on the fables and other Sentani cultural heritage as well as training teachers in their teaching-learning process. Environmentrelated agencies can also think about the reservation of flora and fauna which almot extinct in Sentani which is mentioned in fables, for example, ironwood (Intsia bijuga), soang trees (Xanthostemon sp.), kombouw (Ficus variagata) and several types of sago, cenderawasih, cassowary, kangaroo, crocodile, turtle, hawk, mambruk, cockatoo, kumkum, kandei fish, etc. 
252 Celt: A Journal of Culture, English Language Teaching \& Literature, Volume 20, Number 2, December 2020, pp. 235 - 255

\section{REFERENCES}

Abrams, M. H., \& Harpham, G. (2014). A Glossary of Literary Terms (5th Edition). Cengage Learning. https://books.google.co.id/books?id=X7iAgAAQBAJ

Abrar, M. (2016). Learning from Fables: Moral Values in Three Selected English Stories. Dinamika Ilmu, 16(1), 47. https://doi.org/10.21093/di.v16i1.250

Abu-Rabia, S., \& Yaari, I. (2012). Parent's Attitudes and Behavior, the Learning Environment, and Their Influence on Children's Early Reading Achievement. Open Journal of Modern Linguistics, 02, 170-179. https://doi.org/10.4236/ojml.2012.24022

Ahi, B., Yaya, D., \& Balc1, S. (2014). The Concept of Environment in Folktales from Different Cultures: Analysis of Content and Visuals. International Electronic Journal of Environmental Education, 4, 1-17. https://doi.org/10.18497/iejee-green.64123

Bhattacharya, N. (2019). Environmental Consciousness in Indian Fables: How and What the Pañcatantra can Teach Our Children (pp. 47-51).

Brumfit, C. J., Brumfit, C., \& Carter, R. (1986). Literature and Language Teaching. Oxford University Press. https://books.google.co.id/books?id=G1UFAQAAIAAJ

Chiparausa, B., \& Frederick, M. (2018). The Role of Folktales in the Preservation of Indigenous Knowledge among the Shona: A review based on Aaron C. Hodza's Ngano Dzamatambidzanwa. 707-719. https://www.scecsal.org/publications/papers2018/043_chiparausha_20 18.pdf

Court, D., \& Rosental, E. (2007). Values Embodied in Children's Literature used in Early Childhood Education in Israeli State Schools. Early Childhood Education Journal, 34, 407-414. https://doi.org/10.1007/s10643-006-0140-9

Danandjaja, J. (2002). Folklor Indonesia: Ilmu Gosip, Dongeng, dan lain-lain. Pustaka Utama Grafiti. 
Yektiningtyas, W., \& Silalahi, E., Fables as Media of Environmental Education 253 for Sentani Children in Jayapura Regency, Papua

Dewi, N. (2017). People and Nature in Asian Stories: Reading and Writing Materials for Eco Education. K@ta: A Biannual Publication on the Study of Language and Literature, 19(1), 32-39. https://doi.org/10.9744/kata.19.1.39-46

Ernawati. (2017). Menumbuhkan nilai Pendidikan Karakter Anak Melalui Dongeng Fabel dalam Pembelajaran. Jurnal Pendidikan Dan Pembelajaran Dasar, 4, 120-133.

Fani, T., \& Ghaemi, F. (2011). Implications of Vygotsky's Zone of Proximal Development (ZPD) in Teacher Education: ZPTD and Self-scaffolding. Procedia - Social and Behavioral Sciences, 29, 1549-1554. https://doi.org/https://doi.org/10.1016/j.sbspro.2011.11.396

Finnegan, R. (2003). Oral Traditions and the Verbal Arts: A Guide to Research Practices. Oral Traditions and the Verbal Arts: A Guide to Research Practices, 1-270. https://doi.org/10.4324/9780203393215

Gusal, L. (2015). "Nilai-Nilai Pendidikan dalam Cerita Rakyat Sulawesi Tenggara Karya La Ode Sidu." Jurnal Humanika, 15(3), 1-18. http://ojs.uho.ac.id/index.php/HUMANIKA/article/view/611

Juanda. (2018). Eksplorasi Nilai Fabel sebagai Sarana Alternatif Edukasi Siswa. Jurnal Pendidikan Bahasa Dan Sastra, 18(2), 294-303. https://doi.org/10.17509/bs_jpbsp.v18i2.15517

Laurenson, D., \& Swingewood, A. (1972). The Sociology of Literature. Paladin.

Lazar, G. (1993). Literature and Language Teaching: A Guide for Teachers and Trainers. Cambridge University Press. https://doi.org/10.1017/CBO9780511733048

Leach, M. (2007). Earth Mother Myths and Other Ecofeminist Fables: How a Strategic Notion Rose and Fell. Development and Change, 38, 67-85. https://doi.org/10.1111/j.1467-7660.2007.00403.x

Lustyantie, N., Setyowati, N., \& Rohman, S. (2019). ENVIRONMENT AND HABITUS IN KALIMANTAN FOLKLORE AND PAPUAN FOLK STORIES ECOCRITICAL STUDY. The 28th International Confrence on Literature (ICoL) XXVIII, $1(1), \quad 392-400$. https://doi.org/10.24815/.v1i1.14473 
254 Celt: A Journal of Culture, English Language Teaching \& Literature, Volume 20, Number 2, December 2020, pp. 235 - 255

Modouw, J. 2021. Pendidikan Kontekstual Papua: Untuk Daerah Terpencil, Pengasuhan Anak, Kurikulum Operasional, Proses Belajar dan Penilaian. Yogyakarta: UNY Press.

Normawati. (2016). PENENTUAN CERITA RAKYAT SENTANI, JAYAPURA, KASUARI DAN BURUNG PIPIT SEBAGAI BAHAN BACAAN SISWA SD (The Determination of Sentani, Jayapura Folktale's "Kasuari dan Burung Pipit" as Reading Material of Elementary School Students). METASASTRA: Jurnal Penelitian Sastra, 7, 201. https://doi.org/10.26610/metasastra.2014.v7i2.201-214

Ohee, H. L. \& Keiluhu, H. (2018). Mengenal Ikan-Ikan Danau Sentani. Jurnal Pengabdian Papua, 2(3), 80-85.

Ormrod, J. E., \& Anderman, L. A. (2003). Educational Psychology: Developing Learners (9th ed.).

Silalahi, E. I. B. (2015). Promoting Sentani Cultural Values as Revealed in Sentani Fables. Universitas Cenderawasih.

Silalahi, E. (2021). Ebeu dan Nangga. UNY Press.

Testimony of Kemendikbud. (2016). Kurikulum 2013: Kompetensi Dasar Sekolah Dasar/Madrasah Ibtidaiyah.

Sukmawan, S., \& Setyowati, L. (2017). Environmental Messages as Found in Indonesian Folklore and Its Relation to Foreign Language Classroom. Arab World English Journal, 8, 298-308. https://doi.org/10.24093/awej/vol8no1.21

Yektiningtyas-Modouw, W. (2018). Burung Pipit dan Kasuari (Cerita Rakyat dalam Tiga Bahasa: Indonesia, Sentani, Inggris). UNY Press.

Yektiningtyas-Modouw, W. (2018). Ebi dan Kandei (Cerita Rakyat dalam Tiga Bahasa: Indonesia, Sentani, Inggris). UNY Press.

Yektiningtyas-Modouw, W. (2011). Helaehili dan Ehabla: Fungsinya dan Peran Perempuan Sentani dalam Masyarakat (A. K. Nusa (ed.)).

Yektiningtyas-Modouw, W., \& Karna, S. (2013). Using Folktales to Stengthen Literacy In Papua. Australian and Interntional Journal of Rural Education, 23(3). 
Yektiningtyas, W., \& Silalahi, E., Fables as Media of Environmental Education 255 for Sentani Children in Jayapura Regency, Papua

Yektiningtyas-Modouw, W., \& Modouw, J. (2017). Infusing Culture in English Learning: An Attempt to Preserve Cultural Heritages in Jayapura Municipality, Papua. Language and Language Teaching Journal, 20(01), 40-48. https://doi.org/10.24071/1lt.2017.200105

Yektiningtyas-Modouw, W., \& Morin, I. (2020). Preserving Sentani Folklore to Promote Creative Economy in Jayapura, Papua. International Journal of Innovation, Creativity, and Change, 14(1), 116-133.

Yektiningtyas, W., \& Rafra, P. (2016). The Importance of Rewriting Papua's Folktales for Children. The 4th Literary Studies Conference on Children's Literature in Southeast Asia Fakultas Sastra Universitas Sanata Dharma.

Yektiningtyas, W., \& Gultom, M. (2018) "Preservation of Sentani Language Using Folktales" (DRPM Research Report). Jayapura: Universitas Cenderawasih. 